\title{
Rapid Progesterone Actions on Thymulin-Secreting Epithelial Cells Cultured from Rat Thymus
}

\author{
Gail M. Head $^{a}$ J ames E.G. Downing ${ }^{a}$ Cosima Brucker ${ }^{b}$ Rolf Mentlein ${ }^{c}$ \\ Marion D. Kendalld \\ a Department of Biology, Imperial College, London, UK; ${ }^{b}$ Frauenklinik, Klinikum Innenstadt der LMU, München, and \\ 'Anatomisches Institut, Kiel, Germany; dThymus Laboratory, The Babraham Institute, Cambridge, UK
}

\section{Key Words}

Ion channels · Calcium • Acrosome reaction · Secretion • Thymic epithelial cells

\begin{abstract}
Many soluble factors of neural, endocrine, paracrine and autocrine origin are present in the thymus and modulate its function. Long-term effects of sex steroids have been documented for thymocytes and cells of the thymic microenvironment. In this report we examine rapid actions of progesterone upon aspects of epithelial cell physiology. Progesterone (0.1-10 ì $M$ ) was applied to cultured thymulin-secreting thymic epithelial cells (TSTEC) and changes in transmembrane potential, transmembrane current, intracellular calcium levels and thymulin secretion were assessed. Rapid changes in electrophysiology and intracellular calcium provide evidence for a membrane-bound progesterone receptor in these cells, in addition to classical cytoplasmic receptors. Application of progesterone to TS-TEC caused electrophysiological changes in $56 \%$ of cells ( $n=40$ ), activating an inward current $(-24 \pm 9 \mathrm{pA}$ at 1 ì $M, \mathrm{n}=7, \mathrm{p}<0.02)$ and dose-dependent depolarization (7.1 $\pm 1.8 \mathrm{mV}$ at 1 ì $M$, $\mathrm{n}=19, \mathrm{p}<0.01$ ). Intracellular calcium levels, monitored by the ratiometric fluorescent calcium indicator fura-2, increased within seconds of progesterone (1 I $M$ ) application. Progesterone ( 1 ì $M$ ) increased thymulin levels in
\end{abstract}

supernatant, as measured by ELISA, above the levels in the preapplication period (142 $\pm 16 \%$ of the preapplication period, $n=3, p<0.02$ ). This effect was reduced in the presence of cobalt chloride which blocks voltage-dependent calcium channels. In addition, TS-TEC in culture were immunoreactive to antibody AG7. This antibody was raised to a membrane-bound antigen involved in calcium influx subsequent to progesterone binding in sperm. Thus we suggest that progesterone acts upon many aspects of TS-TEC physiology through both cytoplasmic and membrane-bound receptors.

\section{Introduction}

Many authors have shown that sex steroid levels alter structure and function of the thymic microenvironment [1-8]. Because of the complexity of steroid interactions and catabolism, the effects of progesterone are not clear. Although all of the sex steroids cause involution of the thymus similar to that seen in pregnancy [reviewed in 9], thymic involution at this time is correlated with serum progesterone levels [10]. However, in general it appears that for most parameters so far studied, oestrogens have a greater effect than progesterone [11-14], appearing to arrest thymocyte development at the earliest stage [15].

\section{KARGER \\ Fax +4161306 1234 \\ E-Mail karger@karger.ch} www. karger.com (c) 1999 S. Karger AG, Basel

$1021-7401 / 99 / 0062-0031 \$ 17.50 / 0$

Accessible online at:

http://BioMedNet.com/karger
Prof. M.D. Kendall

The Thymus Laboratory, The Babraham Institute

Cambridge, CB2 4AT (UK)

Tel. +44 1223 832312, Fax +44 1223 837912, E-Mail marion.kendall@bbsrc.ac.uk 
Cytoplasmic receptors for progesterone and oestrogen have been demonstrated in the thymus. Levels of cytoplasmic receptors for these hormones are much lower in lymphoid cells of the thymus than in the stromal cells [1618]. Epithelial steroid receptors were found in the medullary region, especially at the corticomedullary junction with a few positive cells in the subcapsular area [18]. Some of these cells were thymulin immunopositive [19]. Synthesis of cytoplasmic progesterone receptors is increased by oestrogens [17], decreased by progesterone [16, 20], and upregulated in pregnancy [21].

Classically, steroid receptors are considered to be localized in the cytoplasm and to act in a genomic manner. As early as 1942, Selye [4] noted immediate anaesthetic effects of progesterone that are incompatible with a genomic action. However, such effects were slow to be recognized [22]. A clear example of this type of nongenomic action has been supplied by the work on the acrosome reaction whereby rapid direct action of progesterone at the cell membrane initiates calcium influx and capacitates sperm [23]. Membrane-bound progesterone receptors have been recently identified in various cells [2426].

Within thymulin-secreting thymic epithelial cells (TSTEC), the genomic action of sex hormones via the nuclear receptor complexes are indicated by studies that co-localized sex hormone receptors and thymulin in TEC [19] and reports showing long-term alterations in production and expression of thymulin by sex hormone treatment [27]. Steroids also altered prostoglandin production by TEC [28]. Nongenomic mechanisms have been suggested for sex steroid-induced changes in TEC proliferation subsequent to alterations in protein kinase $\mathrm{C}$ levels [29].

In vitro studies of steroid action on thymic epithelial cells demonstrated increased thymulin secretion from cultures of rat and human TEC after long-term incubations with progesterone, testosterone and 17ß-estradiol [27]. The steroids also increased the percentage of thymulinsecreting cells in these cultures suggesting an effect on proliferation. Long-term co-incubation with the progesterone antagonist RU-486 abrogated the progesterone effect. Steroid-induced increases in TS-TEC proliferation were confirmed by Head et al. [30] who also showed decreased intercellular coupling in TS-TEC after incubations with steroids.

This paper investigates rapid actions of progesterone upon a range of physiological parameters of TS-TEC to determine if nongenomic actions of progesterone are present and to clarify that progesterone has direct actions upon these thymic epithelial cells.

\section{Materials and Methods}

\section{Cell Culture}

Thymic epithelial cell cultures were produced, characterized and passaged according to published methods [31]. Three culture media (two with additions from Sigma) were used in the study. A basal medium was used for cell equilibration comprising DMEM/F12 (Gibco) alone. A defined, serum-free medium was used for control incubations, comprising DMEM/F12 plus the following additions: 2 Ì $M$ l-glutamine, $100 \mathrm{U} / \mathrm{ml}$ penicillin/streptomycin and $25 \mathrm{~g} / \mathrm{ml}$ transferrin). The standard culture medium was used for routine culture of the cells, comprising the defined medium plus $10 \%$ horse serum, $5 \mathrm{~g} / \mathrm{ml}$ insulin, $10 \mathrm{ng} / \mathrm{ml}$ cholera toxin and epidermal growth factor $(100 \mathrm{ng} / \mathrm{ml})$. All experiments were carried between passages 20-30 when the culture characteristics are stable [30].

\section{Estimation of Thymulin in Supernatants}

Cultured cells were equilibrated for $1 \mathrm{~h}$ in basal medium. They were then incubated for $2 \mathrm{~h}$ each in the defined medium, or defined medium plus either 1 Ì $M$ progesterone, $2.5 \mathrm{~m} M$ cobalt chloride or 1 İ $M$ progesterone with $2.5 \mathrm{~m} M$ cobalt chloride. After this incubation the cells were returned to the defined medium. The experiment was replicated 3 times. The supernatant from each incubation was reserved and stored at $-70^{\circ} \mathrm{C}$ before estimation of thymulin content by ELISA as previously described [30]. Briefly, each supernatant sample was mixed with an optimal dilution of primary antibody RMK 4 and allowed to equilibrate for $18 \mathrm{~h}$ at $4{ }^{\circ} \mathrm{C}$. Free thymulin in the sample bound excess antithymulin antibody in the liquid phase. In the second step, $120 \mathrm{ml}$ of each sample/RMK4 mixture was transferred to a high binding plate, previously coated with synthetic thymulin, to which any remaining free antibody bound. Thus the amount of free antibody that reacted in this step correlated inversely with the thymulin concentration in the initial sample. The antibody bound to the thymulin, and hence the plate, was reacted with peroxidase-conjugated secondary antibodies, that catalysed colour development of 3,3',5,5'-tetramethylbenzidine in the presence of $\mathrm{H}_{2} \mathrm{O}_{2}$. Colour development was stopped by the addition of $\mathrm{H}_{2} \mathrm{SO}_{4}$ to produce a static endpoint, read as optical density at $450 \mathrm{~nm}$ on a spectrophotometer and compared against a calibration curve (from the same plate) of known concentrations of synthetic thymulin.

\section{Electrophysiology}

TEC cultures were grown in the standard medium in 35-mm dishes for 3 days after passage. The cells were rounded up for recording by a 5 -min incubation in enzyme-free dissociation fluid (Sigma) after which they were equilibrated for $15 \mathrm{~min}$ in a modified Ringer's solution containing $144 \mathrm{~m} M \mathrm{NaCl}, 5.4 \mathrm{~m} M \mathrm{KCl}, 1 \mathrm{mM} \mathrm{MgCl}, 2.5 \mathrm{~m} M$ $\mathrm{CaCl}_{2}, 5.6 \mathrm{~m} M D$-glucose, $5 \mathrm{~m} M$ HEPES and $0.001 \% \mathrm{w} / \mathrm{v}$ phenol red. Intercellular recording solutions contained $140 \mathrm{~m} M \mathrm{KCl}, 5 \mathrm{mM} \mathrm{NaCl}$, $0.5 \mathrm{~m} M \mathrm{CaCl}_{2}, 3 \mathrm{~m} M$ Mg-ATP, $5 \mathrm{~m} M$ EGTA and $10 \mathrm{~m} M$ HEPES. During control and recovery periods the modified Ringer's solution was perfused across the surface of the cell through a gravity feed, Ytube assembly. Differing concentrations of progesterone $(0.1,1$ and 10 İ $M$ ) were made up in modified Ringer's solution and administered through the perfusion apparatus which was quickly interchangeable between control and test solutions. Recordings were made in whole cell current clamp and voltage clamp at $-100 \mathrm{mV}$ to investigate the currents and membrane potential changes induced by progesterone.

Glass micropipette electrodes of resistance between 0.2 and $10 \mathrm{M}$ were applied to the cell at $400 \times$ magnification on an Olympus 
(IMT-2) inverting microscope under phase-contrast illumination. Seals were formed by the application of suction through the microelectrode. Seals with resistance $<1 \mathrm{G} \varnothing$ were discarded. Whole cell current and voltage recordings were obtained using a RK400 patchclamp amplifier (Biologic). DC offsets resulting from junction potentials were corrected. Errors due to series resistance and capacitance were minimized using the compensation circuits of the amplifier. Raw data was displayed on a Schlumberger Enertec 5072 storage oscilloscope. The signal was by, and command pulses routed via, a 1401 interface (Cambridge Electronic Design). Signals were filtered at $1 \mathrm{kHz}$ through a 5-pole Tchebicheff filter, digitized at between 0.1 and $10 \mathrm{kHz}$ using a 1401 interface (Cambridge Electronic Design) and recorded on the hard drive of an IBM compatible 386 computer. Voltage and current commands from the amplifier were remotely controlled from the computer, and analysis performed, using Vclamp software (Cambridge Electronic Design, version 5).

\section{Fluorescent Calcium Imaging}

TEC cultures were grown in the standard medium upon sterile glass coverslips previously coated with poly- $d$-lysine $(1-10 \% \mathrm{v} / \mathrm{v})$ for 3 days after passage. Cells were loaded with the ratiometric calcium indicator fura- 2 either by incubation for $15-60 \mathrm{~min}$, at $37^{\circ} \mathrm{C}$ with 1-10 I $M$ of the AM ester of fura- 2 after being washed in serum-free medium, or by a 30 -min incubation with liposomes (composed of phosphatidylserine, phosphatidylcholine, and cholesterol in a 2:20:10 ratio) containing fura-free acid or fura-2 dextran conjugate, both with the zinc chelating compound $\mathrm{N}, \mathrm{N}, \mathrm{N}^{\prime}, \mathrm{N}^{\prime}$-tetrakis(2-pyridylmethyl)ethylenediamine (TPEN) which was also applied to the cultures for between $30 \mathrm{~min}$ to $2 \mathrm{~h}$ prior to liposome application. After fura-2 incorporation the cultures were washed with modified Ringer's solution ( $140 \mathrm{~m} M \mathrm{NaCl}, 5.4 \mathrm{~m} M \mathrm{KCl}, 1 \mathrm{mM} \mathrm{MgCl}, 10 \mathrm{~m} M$ $\mathrm{CaCl}_{2}, 5.6 \mathrm{~m} M D$-glucose and $5 \mathrm{~m} M$ HEPES) in which they were then equilibrated for $10 \mathrm{~min}$. The coverslip was placed in a recording chamber that was sealed with silicon grease (RS components). The holding vessel was then placed into a heated stage on the microscope and maintained at $37^{\circ} \mathrm{C}$.

The cells were observed using a Nikon inverting microscope with a $40 \times$ objective. Intracellular calcium changes were monitored with a dynamic video imaging system (Applied Imaging MagiCal system Newcastle, UK [32]). Each cell was calibrated at the end of the recording by application of 10 I $M$ calcium ionophore (A23187, Sig$\mathrm{ma})$ in modified Ringer's and in calcium-free Ringer's (140 $\mathrm{mM}$ $\mathrm{NaCl}, 5.4 \mathrm{~m} M \mathrm{KCl}, 1 \mathrm{~m} M \mathrm{MgCl}, 10 \mathrm{~m} M$ EGTA, $5.6 \mathrm{~m} M D$-glucose and $5 \mathrm{~m} M$ HEPES). Cells which did not produce a swift, reversable change in fluorescent ratio to the calibration protocol were excluded from the experiment.

To quantify changes in intracellular calcium in response to progesterone (1 Ì $M$ ), a control wash with modified Ringer's solution only was applied to the recording bath, then the same solution with added progesterone was applied in excess, after an application of $30 \mathrm{~s}$ to $1 \mathrm{~min}$ the compound was washed away by flushing the recording chamber with the control Ringer.

\section{Immunocytochemistry}

TEC cultures were grown in the standard medium for 3 days after passage upon sterile glass coverslips, previously coated with poly- $d$ lysine $(1-10 \% \mathrm{v} / \mathrm{v})$. The cells were fixed in acetone for $2 \mathrm{~min}$ and air dried, after which they could be stored, wrapped in cling film at $-30^{\circ} \mathrm{C}$ for up to 1 week, being defrosted at room temperature, unwrapped and air dried before processing. All reagents were made

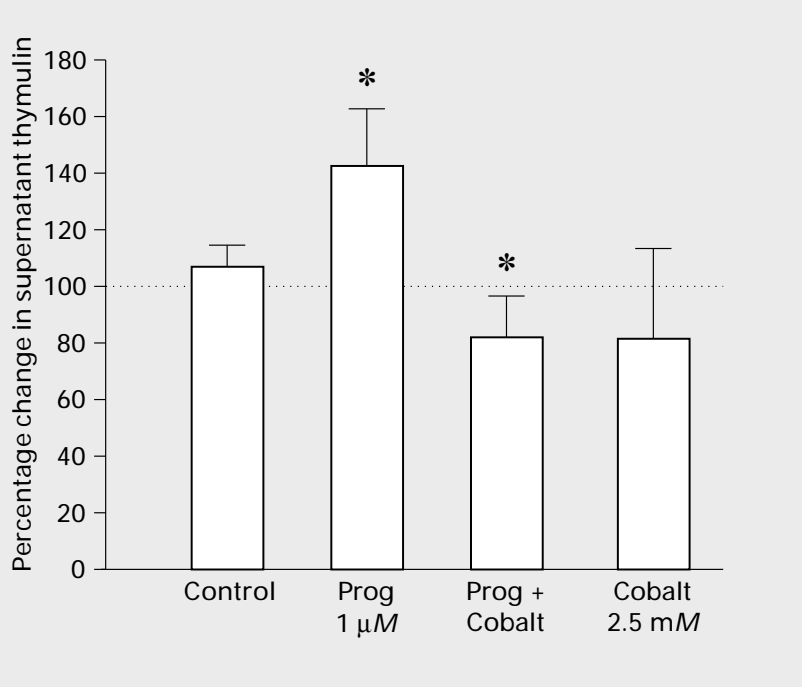

Fig. 1. Mean \pm SEM change in thymulin level compared to a preincubation period of similar duration. Supernatant thymulin levels were determined by ELISA. The known thymulin secretagogue progesterone (Prog) significantly increased the levels of supernatant thymulin. Co-application of cobalt with progesterone prevented the progesterone-induced increase in thymulin levels, a significant reduction compared to the effect of progesterone. Cobalt also reduced basal secretion $(82 \pm 32 \%, \mathrm{n}=3)$ but this change was not significant. $* \mathrm{p}<$ 0.05 .

up in phosphate-buffered saline containing $1 \%$ Triton X (Sigma). A solution containing $0.1 \%$ casein and $0.1 \%$ bovine serum albumin (both from Sigma) was applied to the cells to block nonspecific binding. Immunocytochemistry was performed conventionally using optimally diluted monoclonal antibodies: $4 ß$ (raised to synthetic thymulin by Mary Ritter, London); AG7 (raised to sperm acrosome antigen-1 by Cosima Brucker, Munich) and pan-cytokeratin (Sigma). For negative controls the primary antibody was omitted. The reaction was visualized by enhanced diaminobenzidine and viewed under bright-field illumination.

\section{Statistics}

Data is expressed as mean \pm SEM, and significance analysed using Student's t tests.

\section{Results}

\section{Thymulin Determination}

Supernatant thymulin levels after $2 \mathrm{~h}$ were increased by 1 ì $M$ progesterone (fig. 1) to $142 \pm 16 \%$ of the preapplication period $(\mathrm{p}<0.02, \mathrm{n}=3)$. This increase was not seen in the presence of $2.5 \mathrm{~m} M$ cobalt chloride $(82 \pm 15 \%$ of controls, $\mathrm{n}=3$ ). Cobalt chloride alone caused a slight, but not significant, reduction of thymulin levels ( $82 \pm$ $32 \%$ of controls, $n=3$ ). 

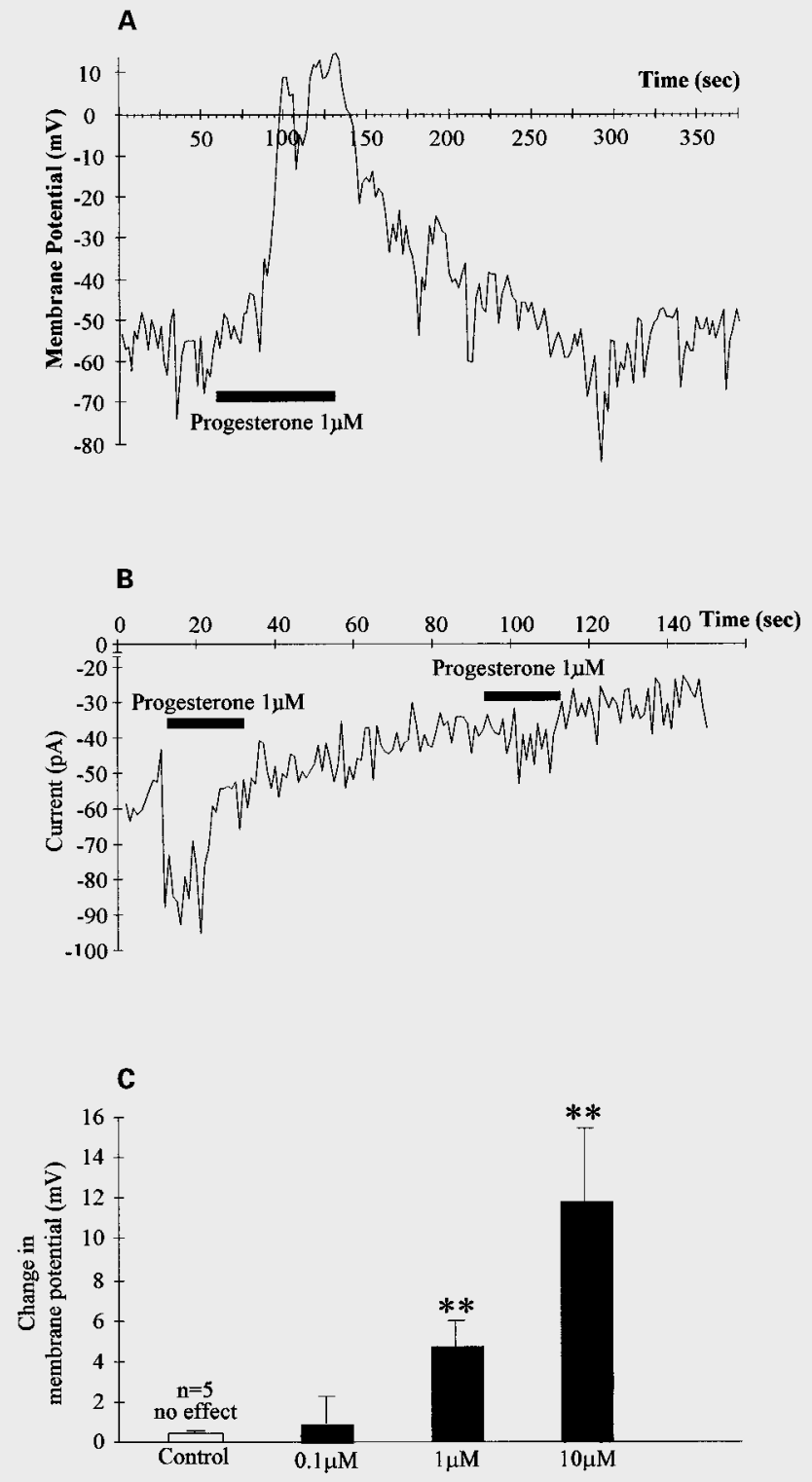

Fig. 2. Electrophysiological effects of progesterone. A Application of progesterone caused a depolarization of the TEC membrane potential. In this case $1 \mathrm{~m} M$ progesterone caused the cell to depolarize from -55 to $+15 \mathrm{mV}$. Most depolarizations were of a smaller magnitude although other depolarizations to positive membrane voltages were seen. B Application of progesterone induced an inward current. Here, repeated applications of $1 \mathrm{~m} M$ progesterone are shown illustrating both the inward current and the desensitization seen. C Depolarization of the cell in response to progesterone was dose-dependent. The mean \pm SEM change in membrane potential of 5-9 cells in response to progesterone at $0.1,1.0$ and $10 \mathrm{~m} M$ is shown. ${ }^{* *} \mathrm{p}<$ 0.01 .

\section{Electrophysiology}

Progesterone induced membrane depolarizations $(\$ E m)$ and inward currents $(\$ I)$ in $56 \%$ of TEC $(n=40)$. Illustrations of these responses are shown in figure $2 \mathrm{~A}$ and $B$ respectively. Responses were desensitizing, a second sequential application having a lower effect $(36 \pm 12 \%$ of 1 st application, $\mathrm{n}=7, \mathrm{p}<0.05$, pooled Em and I) as shown in figure 2B. The mean inward current induced by $1 \mathrm{Ì} M$ progesterone was $-24 \pm 9 \mathrm{pA}(\mathrm{n}=7, \mathrm{p}<0.02)$. Depolarizations of up to $22 \mathrm{mV}$ resulted from the application of progesterone (mean $\pitchfork \mathrm{Em}=7.1 \pm 1.8 \mathrm{mV}$ at $1 \mathrm{I} M, \mathrm{n}=19$, $\mathrm{p}<0.01)$. These sometimes took the cell to positive membrane voltages (fig. 2A). Depolarizations were dose-dependent $(100 \mathrm{n} M, \$ \mathrm{Em}=-1.1 \pm 1.5 \mathrm{mV} ; 1 \mathrm{I} M, \$ \mathrm{Em}=$ $4.6 \pm 1.3 \mathrm{mV}, \mathrm{p}<0.05 ; 10$ Ì $M, \phi E \mathrm{Em}=11.9 \pm 3.7 \mathrm{mV}$, $\mathrm{p}<0.05$; all $\mathrm{n}=7$, paired recordings; fig. $2 \mathrm{C}$ ). The reversal potential of the current was at $+41 \pm 14 \mathrm{mV}(\mathrm{n}=7)$. In addition, depolarizing responses became hyperpolarizing after substitution of extracellular sodium with choline in 5 cells $(\phi E m=+4 \pm 1 \mathrm{mV}$ to $\phi E m=-5 \pm 2 \mathrm{mV}, \mathrm{n}=5, \mathrm{p}<$ $0.02)$, implicating sodium as a major permeant ion.

\section{Fluorescent Calcium Imaging}

In cells with adequate ionomycin calibration intracellular calcium was increased following application of 1 ì $M$ progesterone $(n=10 / 30, p<0.001)$. The temporal and spatial response characteristics of a progesterone-evoked calcium signal are shown in figure 3 . The peak intracellu-

Fig. 3. This figure shows the change in nominal intracellular calcium (y-axis) with time (x-axis) in the cell shown as an inset. The pseudocolour scale within the y-axis shows the relationship between colour and calcium concentration used to produce the pseudocolour image of the calcium concentration within the cell (inset) during the response to 1 I $M$ progesterone (frame position is indicated by the white star). The progesterone application, to wash out the control ringer, took place during the period marked by the white bar. Progesterone caused a rapid, reversible increase in intracellular calcium of this TEC. Progesterone remained in the chamber until the end of this recording, after which a response to calcium ionophore was obtained (not shown).

Fig. 4. Immunoreactivity of TEC, 3 days after passage, for antibodies to AG7 (A), thymulin (B), and cytokeratin (C). The scale is given by the scale bar in $\mathbf{A}$ which represents $10 \mathrm{II} \mathrm{m}$. A Immunoreactivity to AG7 was observed in all cells and was distributed fairly evenly. Small cells and those near the edge of the monolayer were in general more intensely stained. B Thymulin staining of TEC. All cells showed a positive reaction. C Cytokeratin was seen in all cells, forming a network through the cell body. Cells at the edges of monolayers were more intensely stained than those in the centre. Single cells were invariably darkly stained. 

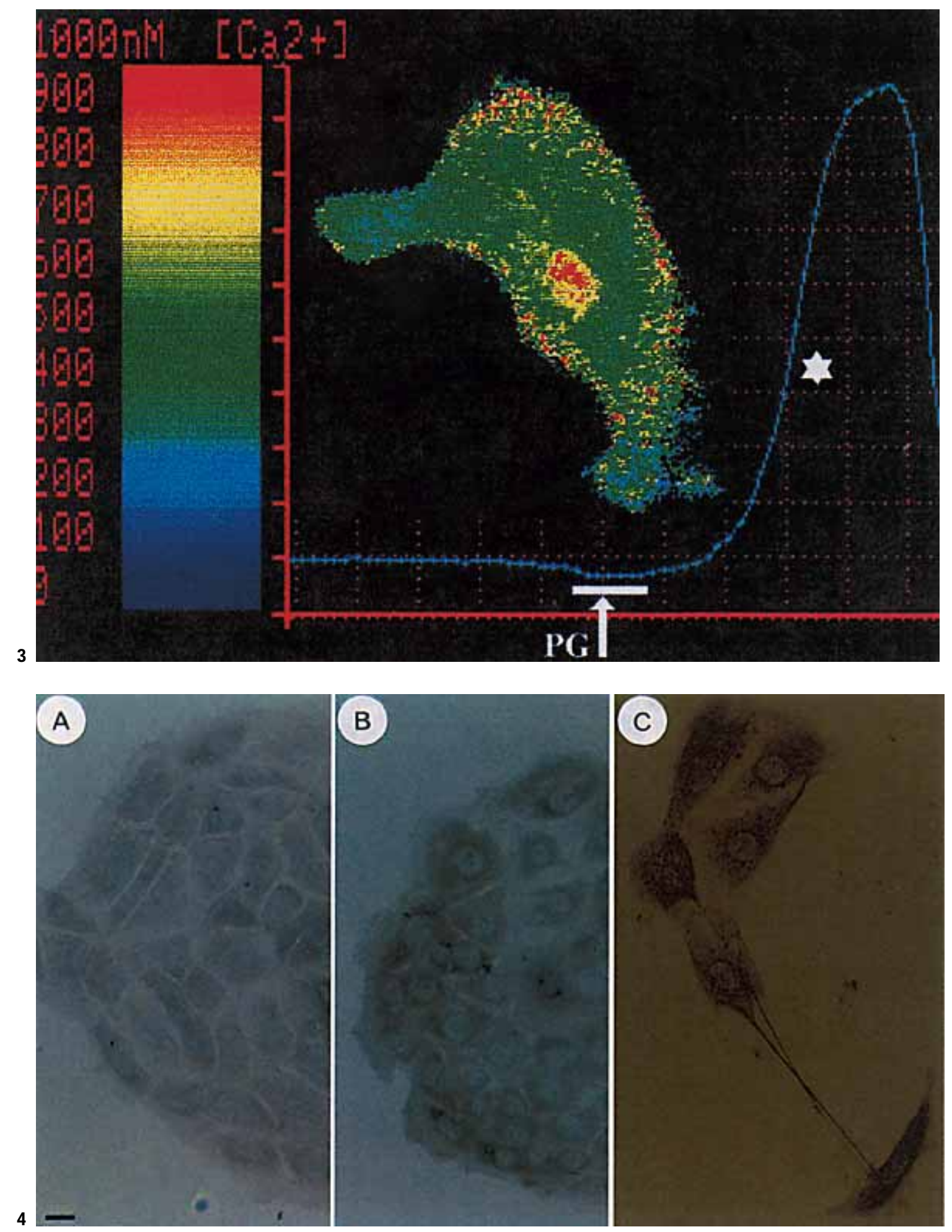
lar calcium levels were achieved 4-6 min after application of 1 Ì $M$ progesterone. Changes in intracellular calcium were not evenly distributed over the cell. The highest levels were seen in some areas of the cell border and in the nucleus. No changes were seen with vehicle control (29 cells).

\section{Immunocytochemistry}

Cultured cells were immunoreactive for cytokeratin, thymulin and AG7 (fig. 4). No unstained cells were observed with these antibodies. No negative controls were stained.

\section{Discussion}

TEC are potential targets of neuroendocrine ligands present in the circulation [33-35] and of input from the thymic innervation [36-39]. Ionic mechanisms of TEC have previously been implicated in thymulin secretion $[40,41]$. The present study and our previous work show that TS-TEC possess ligand-induced adrenergic and steroidal mechanisms $[42,43]$.

Here we demonstrate direct actions of progesterone upon various physiological responses of TS-TEC. Classically, progesterone action involves cytoplasmic steroid receptors that induce changes in DNA transcription. These receptors are present on TEC and steroid-induced changes in thymic physiology and thymulin secretion have mainly been ascribed to genomic action [18, 27]. Some of the progesterone-induced responses previously demonstrated by us in these cells [30], namely a reduction in intercellular coupling and an increase in proliferation, may be partly due to such genomic responses. However, the electrophysiological changes and calcium flux initiated by progesterone in this study occur too rapidly to be genomic effects. The inhibition of progesterone-evoked secretion by cobalt also suggests that short-term $(2 \mathrm{~h})$ changes in thymulin release are a direct effect of calciumdependent exocytosis rather than of increased thymulin expression.

Both electrophysiological recordings and calcium imaging suggest that nongenomic responses may not occur in all cells. This could be a reflection of the morphological heterogeneity of the cultures [30] and their variable expression of ion channels [44].

Electrophysiological responses of TEC were observed in response to the application of progesterone. These responses comprised the activation of transmembrane currents and changes in transmembrane voltages that were desensitizing and dose-dependent. These changes were consistent with the activation of a poorly selective cation current. This is a novel action of progesterone in somatic cells. It is not consistent with established actions, whereby progesterone and/or its metabolites increase and prolong the Áaminobutyric acid-A chloride current [45] or inhibit cation currents stimulated by cholinergic agonists at nicotinic acetylcholine receptors [46].

Poorly selective cation currents activated by progesterone have also been reported in sperm which result in an influx of sodium and calcium activating the acrosome reaction [47]. A membrane-bound receptor initiating a nongenomic signal transduction pathway has been implicated in this effect. The membrane-bound sperm acrosome antigen-1 (SAA-1), that is internalized after progesterone binding, forms part of this pathway [48]. SAA-1 is recognized and inhibited by the antibody AG7 [1]. SAA-1 could be a progesterone receptor, a separate ion channel or an accessory protein [48]. The positive immunoreactivity to AG7 suggests that a similar mechanism may be present in TS-TEC. Furthermore, the characteristics of the current induced in sperm by progesterone are comparable to those seen in TEC, and both result in rapid calcium influx.

The nongenomic progesterone receptor in TS-TEC has not yet been characterized and no details of its structure or molecular weight are known. Functionally we have demonstrated that in TS-TEC, activation of this progesterone receptor leads to ion channel activation. Although progesterone membrane-binding proteins have been found in a number of cell types [26], none of them have been shown to activate ion channels. Three hypothetical mechanisms, whereby the progesterone receptor of TEC may open an ion channel, are presented in figure 5. Firstly, the receptor may be metabotropic, coupling to a separate ion channel via second messengers (fig. 5A). Secondly, the receptor may be a membrane-bound protein that aggregates as a subunit or component of an ion channel (fig. 5B). Thirdly, the receptor may incorporate an ion channel, allowing it to be directly ionotropic (fig. 5C). Any of these models may allow calcium influx through the channel, although in such nonselective cation channel the proportion of calcium is likely to form only a small proportion of the current. The large calcium influx seen suggests the presence of voltage-gated calcium channels that open in response to the progesterone-induced depolarization. This hypothesis is supported by the inhibition of secretion seen with cobalt.

A functional consequence of an influx of calcium is the secretion of thymulin [40, 41]. Thus calcium influx could 
Fig. 5. Models of nongenomic progesterone signal transduction in TS-TEC. A Progesterone binds to a novel membrane-bound receptor which activates an ion channel via second messengers. B Progesterone binds to a novel membrane-bound receptor which activates an ion channel by associating with the ion channel molecule. C Progesterone binds to a novel ionotropic receptor. D Although calcium influx may occur through the initial channel (A) it may be augmented through cell depolarization and the subsequent opening of voltage-dependent calcium channels. Additional signals initiated by progesterone are mediated by cytoplasmic receptors and genomic action.

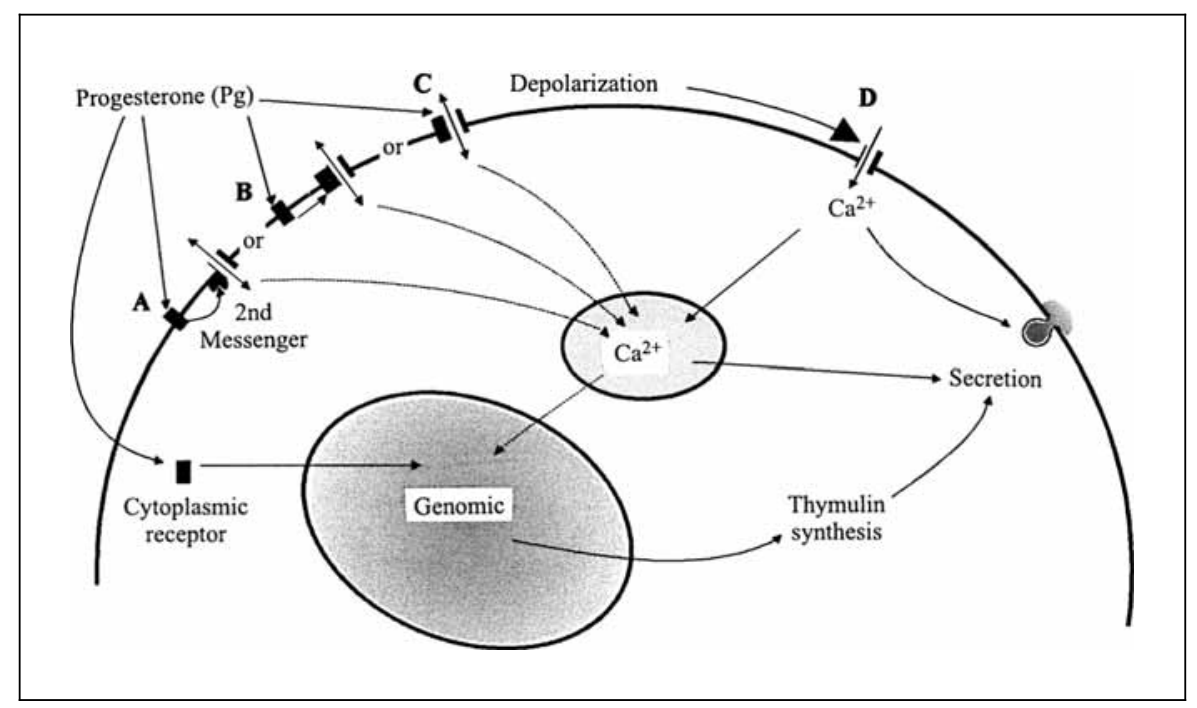

explain the rapid progesterone-mediated secretion of thymulin through non-genomic pathways. These are in addition to the documented long-term effects of progesterone upon thymulin synthesis and cell proliferation $[27,30]$.

\section{Conclusions}

The thymus, as one of the primary lymphoid organs, plays a crucial role in immunological defence and its output can be altered by neural and endocrine stimuli. These stimuli can act upon immature thymocytes but also affect the stromal cells of the gland which create the thymic microenvironment and provide developmental cues for the thymocytes.

The stromal cells of the thymus do not appear to be a static, structural framework, carrying out predetermined steps in thymocyte differentiation. The results of this and our previous studies show that TS-TEC form a plastic network that is highly responsive to a wide range of inflammatory, neuroendocrine and neural signals.

The range of ligands to which these cells respond suggest that ligands have coordinate actions upon these cells. The large number of inputs may suggest that TS-TEC are involved in signal recognition and processing for the thymic-immune axis.

This paper confirms progesterone to be one of the factors capable of stimulating TS-TEC to modulate aspects of their physiology. The ligand-induced responses of TSTEC are diverse. Progesterone acting through a combina- tion of genomic and nongenomic actions influences proliferation, secretion, the degree of communication between epithelial cells and hence modulates interactions with thymocytes.

\section{Acknowledgments}

G.M.H. was supported by the Medical Research Council, and J.E.G.D. by the Royal Society, with additional support provided by the University of London Central Research Fund and Smith Kline (1982) Foundation. R.M. and M.D.K. are funded by the Volkswagen Stiftung, and M.D.K. would like to thank the Welton Foundation for additional financial assistance. 


\section{References}

1 Brucker C, Kassner G, Loser C, Hinrichsen M, Lipford GB: Progesterone-induced acrosome reaction - Potential role for sperm acrosome antigen-1 in fertilization. Hum Reprod 1994;9: 1897-1902.

2 Persike EC: Involution of the thymus during pregnancy in young mice. Proc Soc Exp Biol Med 1940;45:315-317.

3 Grégoire C: Sur le méchanisme de l'atrophie thymique déclenchée par les hormones sexuelles. Arch Intern Pharmacodyn 1945;70:4577.

4 Selye H: The general adaption syndrome and the disease of adaption. J Clin Endocrinol 1942;6:117-230.

5 Dougherty TF: Effect of hormones on lymphatic tissue. Physiol Rev 1952;32:379-401.

6 Stimson WH, Hunter IC: Oestrogen-induced immunoregulation mediated through the thymus. J Clin Lab Invest 1980;4:27-33.

7 Grossman CJ: Regulation of the immune system by sex steroids. Endocr Revs 1984;5:435455.

8 Greenstein BD, Fitzpatrick FTA, Adcock IM, Kendall MD, Wheeler MJ: Reappearance of the thymus in old male rats after orchidectomy: Inhibition of regeneration by testosterone. $\mathbf{J}$ Endocrinol 1986;110:417-422.

9 Kendall MD, Clarke AG: The female thymus and reproduction in mammals. Oxf Rev Reprod Biol 1994;16:165-213.

10 Chambers SP, Clarke AG: Measurement of thymus weight, lumbar node weight and progesterone levels in syngeneically pregnant, allogeneically pregnant and pseudopregnant mice. J Reprod Fertil 1979;55:309-315.

11 Bimes C, de Graeve P, Guilhem A, Amiel S: La cytologie thymique sous l'action des hormones genitales chez le cobaye. C R Séanc Soc Biol Fil 1975;169:233-238.

12 Hellig HR, Gerneke WH: A histological study of the effect of cortisol and some six steroids on the immune response to sheep erythrocytes by the mouse. Onderstepoort J Vet Res 1975;42: 53-62.

13 Stimson WH, Crilly PJ: Effects of steroids on the secretion of immunoregulatory factors by thymic epithelial cell cultures. Immunology 1981;44:401-407.

14 Fitzpatrick FT, Greenstein BD: Effects of various steroids on the thymus, spleen, ventral prostate and seminal vesicles in old orchidectomized rats. J Endocrinol 1987;113:51-55.

15 Rijhsinghani AG, Thompson K, Bhatia SK Waldschmitt TJ: Estrogen blocks early T-cell development in the thymus. Am J Reprod Immunol 1996;36:269-277.

16 Pearce PT, Khalid BAK, Funder JW: Progesterone receptors in rat thymus. Endocrinology 1983;113:1287-1291.

17 Fujii-Hanamoto H, Seiki K, Sakabe K, Ogawa $\mathrm{H}$ : Progestin receptor in the thymus of ovariectomized immature rats. J Endocrinol 1985; 107:223-229.

18 Sakabe K, Seiki K, Fujiihanamoto H: Histochemical localization of progestin receptor cells in the rat thymus. Thymus 1986;8:97-107.
19 Kawashima I, Sakabe K, Seiki K, Fujiihanamoto H, Akatsuka A, Tsukamoto H: Localization of sex steroid-receptor cells, with special reference to thymulin (FTS)- producing cells in female rat thymus. Thymus 1991;18:79-93.

20 Pasqualini JR, Gulino A, Sumida C, Screpanti I: Anti-oestrogens in fetal and newborn target tissues. J Steroid Biochem 1984;20:121-128.

21 Pearce P, Funder JW: Cytosol and nuclear levels of thymic progesterone receptors in pregnant, pseudopregnant and steroid-treated rats. J Steroid Biochem 1986; 25:65-69.

22 Wehling M: Specific, nongenomic actions of steroid hormones. Annu Rev Physiol 1997;59: 365-393.

23 Meizel S, Turner KO: Progesterone acts at the plasma-membrane of human sperm. Mol Cell Endocrinol 1991;77:R1-R5.

24 Meyer C, Schmid R, Scriba PC, Wehling M: Purification and partial sequencing of highaffinity progesterone-binding site(s) from porcine liver membranes. Eur J Biochem 1996; 239:726-731.

25 Falkenstein E, Meyer C, Eisen C, Scriba PC, Wehling M: Full-length cDNA sequence of a progesterone membrane-binding protein from porcine vascular smooth muscle cells. Biochem Biophys Res Commun 1996;229:86-89.

26 Eisen C, Meyer C, Wehling M: Characterization of progesterone membrane binding sites from porcine liver probed with a novel azidoprogesterone radioligand. Cell Mol Biol 1997; 43:165-173.

27 Savino W, Bartoccioni E, Homo-Delarche F, Gagnerault M, Itoh T, Dardenne M: Thymic hormone containing cells. IX. Steroids in vitro modulate thymulin secretion by human and murine thymic epithelial cells. J Steroid Biochem 1988;30:1-6.

28 Homo F, Russo-Marie F, Papiernik M: Prostaglandin secretion by human thymic epithelium: In vitro effects of steroids. Prostaglandins 1981;22:377-385.

29 Sakabe K, Kawashima I, Urano R, Seiki K, Itoh T: Effects of sex steroids on the proliferation of thymic epithelial cells in a culture model - A role of protein kinase C. Immunol Cell Biol 1994;72:193-199.

30 Head GM, Mentlein R, Kranz A, Downing JEG, Kendall MD: Modulation of dye-coupling and proliferation in cultured rat thymic epithelium by factors involved in thymulin secretion. J Anat 1997;191:355-365.

31 Kurz B, von Gaudecker B, Kranz A, Krisch B, Mentlein R: Rat thymic epithelial cells in vitro and in situ - Characterization by immunocytochemistry and morphology. Cell Tissue Res 1996;283:221-229.

32 Mason WT, Hoyland J, Neylon CB, Kato M, Ackerman S, Bunting R, Tregear RT, Zorec R: Dynamic, real-time imaging of fluorescent probes of biological activity in living cells. J Med Lab Sci 1991;5:41-52.

33 Dardenne M, Savino W: Neuroendocrine control of the thymic epithelium: Modulation of thymic endocrine function, cytokine expression and cell proliferation by hormones and peptides. PNEI 1990;3:18-25.
34 Millington G, Buckingham JC: Thymic peptides and neuroendocrine-immune communication. J Endocrinol 1992;133:163-168.

35 Kendall MD, Stebbings RJ: The endocrine thymus. Endocr J 1994;2:333-339.

36 Kendall MD, Al-Shawaf A: Innervation of the rat thymus gland. Brain Behav Immun 1991;5: 9-28.

37 Kendall MD, Atkinson BA, Munoz F, De La Riva C, Clarke A, von Gaudecker B: The noradrenergic innervation of the thymus during pregnancy and in the post-partum period. $\mathbf{J}$ Anat 1994; 185:617-625.

38 Kurz B, Feindt J, von Gaudecker B, Kranz A, Loppnow H, Mentlein R: B-Adrenoceptor-mediated effects in rat cultured thymic epithelial cells. Br J Pharmacol 1997;120:1401-1408.

39 Head GM, von Patay B, Mentlein R, Downing JEG, Kendall MD: Neuropeptides exert direct effects on rat thymic epithelial cells in culture. Dev Immunol 1998;6:95-104.

40 Buckingham JC, Safieh B, Singh S, Arduino LA, Cover PO, Kendall MD: Interactions between the hypothalamo-pituitary-adrenal axis and the thymus in the rat: A role for corticotrophin in the control of thymulin release. J Neuroendocrinol 1992;4:295-301.

41 Head GM, Kendall MD, Downing JEG: Intrinsic ionic mechanisms contribute to the control of thymulin release from thymic epithelia of rat in vitro. J Physiol 1998, in press.

42 Head GM, Kendall MD, Downing JEG: Adrenergic modulation of thymulin release and electrophysiological changes in cultured epithelium from rat thymus (abstract). 3rd Annu Meet of the Brain-Immune Network Group (BING), London, September 1997.

43 Head GM, Kendall MD, Kranz A, Brucker C, Downing JEG: Modulation of rat thymic epithelial cell physiologies in vitro by progesterone may involve non-genomic mediation through sperm acrosome antigen-1 (abstract). 3rd Annu Meet of the Brain-Immune Network Group (BING), London, September 1997.

44 Head GM, Downing JEG: Anionic leak conductance and macroscopic outward currents of cultured secretory epithelia from rat thymus. $\mathbf{J}$ Physiol 1996;495P:108P.

45 Lambert JJ, Belelli D, Hill-Venning C, Peters JA: Neurosteroids and $\mathrm{GABA}_{\mathrm{A}}$ receptor function. Trends Pharmacol Sci 1995; 16:295-303.

46 Bullock AE, Clark AL, Grady SR, Robinson SF, Slobe BS, Marks MJ, Collins AC: Neurosteroids modulate nicotinic receptor function in mouse striatal and thalamic synaptosomes. $\mathrm{J}$ Neurochem 1997;68:2412-2423.

47 Garcia MA, Meizel S: Importance of sodium ion to the progesterone-initiated acrosome reaction in human sperm. Mol Reprod Dev 1996;45:513-520.

48 Brucker C, Sandow BA, Blackmore PF, Lipford GB, Hodgen GD: Monoclonal antibodyAG7 inhibits fertilization post sperm-zona binding. Mol Reprod Dev 1992;33:451-462. 